\title{
Calvert versus Carroll The Quit-rent Controversy between Maryland's Founding Families
}

By:

\author{
Garrett Power \\ Professor \\ University of Maryland \\ School of Law ${ }^{1}$
}

\section{Table of Contents}

INTRODUCTION …

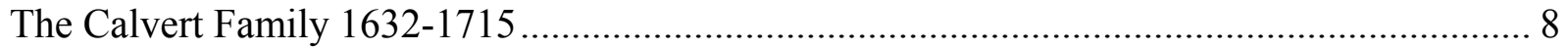

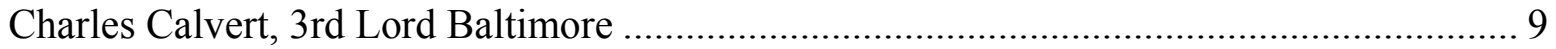

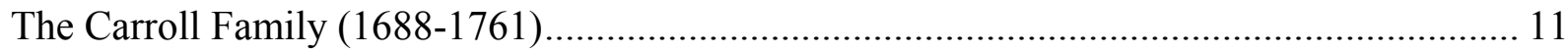

Charles Carroll the Settler......................................................................................... 11

The Calvert Family (1715-1771) ....................................................................................... 16

Charles Calvert, the 5th Lord Baltimore (1715-1751) ..................................................... 16

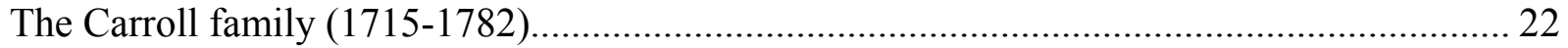

Henry Harford (1781-1783) ………………………………………………………. 24

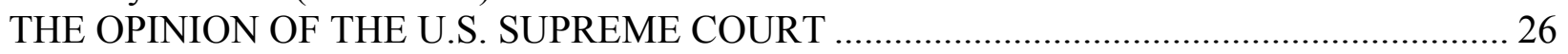

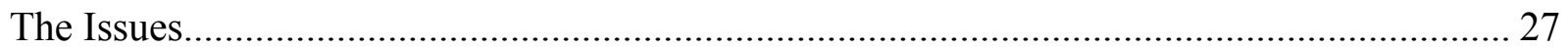

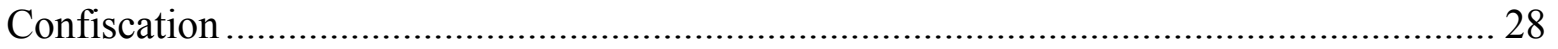

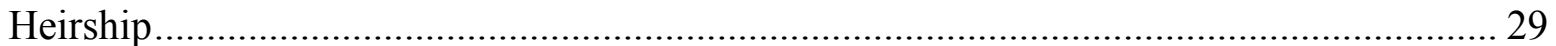

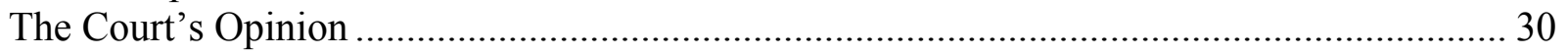

Historical Significance ...................................................................................................... 31

A Triumph of Capitalism over Feudalism ....................................................................... 31

Money, Value and Exchange …………………………................................................... 32

"An act of naked judicial legislation"................................................................................... 34

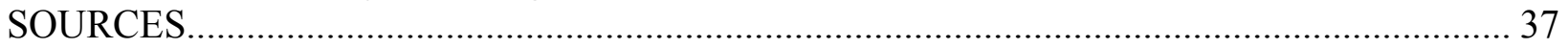

Appendix 1. Cassell v.Carroll Chronology ............................................................................... 40

\footnotetext{
${ }^{1}$ Prepared with a Research Grant from the University of Maryland School of Law. The author thanks law student Scott Krygier for research assistance and Ryan Easely of the University Maryland Law Library for editorial assistance. Bill Sleeman of the University Maryland Law Library and Jennifer Hafner of the Maryland State Archives also provided research assistance.
} 


\section{INTRODUCTION}

Charles Browning visited Maryland in 1819. He was citizen of Great Britain who had come to claim the Calvert family fortune. For seven generations, between 1632 and 1776, the Calverts had been the Barons of Baltimore and the Lord Proprietors of the province of Maryland. But when the people of Maryland declared their independence the new government had confiscated all British property, including the property still owned by the Barons of Baltimore. Moreover, the landholders of Maryland had stopped paying the annual quit-rents they owed on the grants they had received from the Lord Proprietors. ${ }^{2}$ Charles Browning as the only child of the legal Calvert heir, Louisa Calvert Browning, came to seek recompense for his birthright. He estimated the overall Calvert family losses at $£ 400,000 .^{3}$

Charles Browning attributed the forty year delay in presenting his claim to circumstance. He alleged that his uncle, Frederick Calvert, the $6^{\text {th }}$ Lord Baltimore, had died in 1771 without legitimate offspring. He claimed that his mother Louisa Calvert Browning (Frederick's oldest sister) had been a lunatic when she inherited province. Charles further explained that he only had learned of his mother's entitlement to the proprietorship of Maryland many years later and that he had been pursuing the Calvert fortune ever since. ${ }^{4}$

In 1820 Browning "humbly" presented his claim, seeking "such compensation for the heavy losses his family have [sic] sustained, as the liberality of the General Assembly of Maryland may think fit to grant." He asked the

\footnotetext{
21780 Md. Laws ch. 18, 45.

${ }^{3}$ Charles Browning, An Appeal to the Citizens of Maryland 17 (Baltimore, T.R. Lusby 1821). [from the John Work Garrett Library of the Johns Hopkins University] Under the then prevailing exchange rate, $£ 400,000$ would have been equal to $\$ 1,752,000$. (The exchange rate of 4.38 is derived from information circuit court record in Appellate Record for the United States District Court for the District of Maryland at 1, Cassell v. Carroll (4th Cir. 1823) (found in the Appellate Case Files of the U.S. Supreme Court, 1792-1831. Microfilm M214, roll number 65, case file number 1263 housed at the National Archives)). The purchasing power in 2003 of (1823) \$1,752,000 is \$30,599,375.24. See John J. McCusker, Economic History Services, Comparing the Purchasing Power of Money in the United States (or Colonies) from 1665 to 2003 (2004), at http://www.eh.net/hmit/ppowerusd/.

${ }^{4}$ Charles Browning, An Appeal to the Citizens of Maryland 5 (Baltimore, T.R. Lusby 1821); Charles Browning, AN ABSTRACT OF THE CONDITION OF GRANTING OF LANDS IN Maryland, As Propounded by Cecilius Lord BARON of Baltimore 7 (Baltimore, Printed for the Proprietor 1825). These pamphlets are in the John Work Garrett Collection of the Johns Hopkins University.
} 
Assembly: "Can there be any grounds for confiscating the property of an Insane Female and her Infant Son?" The Assembly answered by awarding him nothing. ${ }^{5}$

The following year Louisa Calvert Browning died without a will, leaving Charles Browning as her heir at law. Henry Cassell qualified as Louisa's administrator and Browning, unable to get satisfaction from the Maryland legislature, prevailed upon Cassell to bring suit against Charles Carroll of Carrollton to collect the quit-rents allegedly due from Carroll on the 10,000 acre Doughoregan Manor. ${ }^{6}$

These quit-rents were the feudal device through which the Barons of Baltimore had reserved a perpetual stream of revenue when they granted vacant proprietary lands to private owners by way of deeds they called patents. ${ }^{7}$ A 1711 patent had granted Doughoregan Manor to Charles Carroll of Carrollton's grandfather, Charles Carroll the settler, and required payment to the Lord Proprietor of a yearly "Rent of Twenty pounds Ster. in Silver or gold."

The 1825 Cassell v. Carroll lawsuit pitted the scions of Maryland's two leading families, one against the other. The plaintiff Cassell represented Charles Browning who claimed to be the legitimate heir to the Calvert family fortune. The Calverts, the Barons of Baltimore, had founded the province of Maryland in 1632. The Carrolls were Maryland's largest landholders, and the defendant Charles Carroll of Carrollton was the last living signer of the Declaration of Independence. ${ }^{9}$

\footnotetext{
${ }^{5}$ Charles Browning, An Appeal to the Citizens of Maryland 34, 36 (Baltimore, T.R. Lusby 1821).

${ }^{6}$ Doughoregan has various spellings: Doohoragen, Doughoreagan, Dooughreagan.

${ }^{7}$ Cassell v. Carroll, 24 U.S. (11 Wheaton) 134 (1826); ClarenCE P. Gould, The Land System IN MARYLAND 1725-1765 (1913).

${ }^{8}$ LAND OFFICE (Patent Record) Charles Carroll's "Doughoregan", 1711, Liber PL 4 ff. $375-$ 376, MSA S 11-52, MdHR 17,377. [The citation format is that used by the Maryland State Archives. Doughoregan Manor had first been warranted to Charles Carroll the Settler, in 1699 as a 7,000 acre tract. Subsequent grants from the proprietor's land agent added 3000 acres. Under a unique arrangement with Charles Calvert, the $3^{\text {rd }}$ Lord Baltimore, the first rental payment did not fall due until 1723 when the Settler's son Charles Carroll of Annapolis reached twenty one years. See Ronald Hoffman, Princes of Ireland, Planters of Maryland: A CARroll SAGA, 1500-1782 (2000).

${ }^{9}$ Sally Mason, Charles Carroll and his Family, 1688-1832, in BALTIMORE MuSEum OF ART,

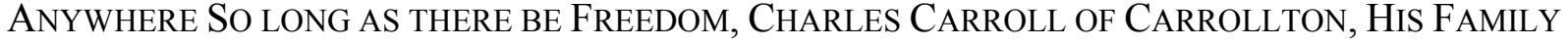
AND HIS MARYLAND 9 (An Exhibition and Catalogue 1975).
} 
The quit-rents in question were agreed to amount to $£ 850$ and were said to be equal to $\$ 3,724 .^{10}$ Although such a piddling sum was of little concern to the wealthy Carroll, from the viewpoint of landholders in Maryland, the stakes were high. The quit-rents claimed were for a period between 1771 (the death of Frederick Calvert, $5^{\text {th }}$ Lord Baltimore) and 1780 (Maryland's statutory abolition of quit-rents). When Frederick the $6^{\text {th }}$ Lord Baltimore had died in 1771 the sum total of all the quit-rents owed by all Maryland landholders to the Lord proprietor had been estimated to be $£ 8,518$ per year. At $5 \%$ interest that annual amount has a capital value of $£ 170,366$, or $\$ 746,203$ if exchanged for 1823 dollars. $^{11}$

If Browning's estate was successful in collecting unpaid rents from Carroll for the years 1771 through 1780 then other collection actions against other landholders sure to follow. Perhaps $\$ 750,000$ (\$ 13 million in today's dollars) was at stake. And if compound interest were added to these debts the amount would be much larger. ${ }^{12}$

Suit was filed on Browning's behalf in the United States District Court for the District of Maryland. At the trial the jury had reached a special verdict for the defendant, and the judges (Associate Supreme Court Justice Gabriel Duvall and Circuit Judge Theodorick Bland) gave judgment for Carroll. The decision was appealed to the United States Supreme Court.

\footnotetext{
${ }^{10}$ Appellate Record for the United States District Court for the District of Maryland at 1, 3, Cassell v. Carroll (4th Cir. 1823) (found in the Appellate Case Files of the U.S. Supreme Court, 1792-1831. Microfilm M214, roll number 65, case file number 1263 housed at the National Archives).

${ }^{11}$ Appellate Record for the United States District Court for the District of Maryland at 1, 3, Cassell v. Carroll (4th Cir. 1823) (found in the Appellate Case Files of the U.S. Supreme Court, 1792-1831. Microfilm M214, roll number 65, case file number 1263 housed at the National Archives); Memorial of Henry Harford (1786) (Text of the Memorial and the Proceedings thereon, published by order of the House of Delegates, General Assembly of Maryland), reprinted in VERA F. ROLLO, HENRY HARFORD: LAST PROPRIETOR OF MARYLAND 141, 143 (1976).

12 Appellate Record for the United States District Court for the District of Maryland at 1-4, Cassell v. Carroll (4th Cir. 1823) (found in the Appellate Case Files of the U.S. Supreme Court, 1792-1831. Microfilm M214, roll number 65, case file number 1263 housed at the National Archives). The sum of \$746,203 in 1823 dollars would today have the purchasing power of over $\$ 13$ million. See John J. McCusker, Economic History Services, Comparing the Purchasing Power of Money in the United States (or Colonies) from 1665 to 2003 (2004), at http://www.eh.net/hmit/ppowerusd/.
} 
John Eager Howard was one of Maryland's most distinguished citizens. A landed aristocrat and military hero of the War for American Independence he had since served Maryland as a state legislator, Governor and U.S. Senator. He had accumulated great wealth by parceling out land on the west side of burgeoning Baltimore Town and he therefore had a substantial stake in the outcome of Cassell v. Carroll. In 1825 he published and distributed 500 copies of a pamphlet for the consideration of the "Landholders of the State of Maryland." His pamphlet solicited sums of money from those landholders interested in contributing to the defense of Charles Carroll from Cassell's appeal. ${ }^{13}$

The legal merits in the case of Cassell $v$. Carroll concerned the arcane question of whether the seigniory and proprietorship of Maryland could be aliened or devised. Feudal concepts of family settlement, entail, sub-infeudation and common recovery might well have provided the answers. But the United States Supreme Court crafted an opinion that avoided these issues and left the property questions, forever unanswered and largely forgotten.

Today the case of Cassell v. Carroll is of little jurisprudential significance. It is the historical record behind the case that tells a story that continues to be of interest and importance today. It provides a window on the political, economic, and social life in provincial Maryland. It tells the tale of two dysfunctional dynastiesthe Barons of Baltimore (the Calverts), who lost their faith, their fortune and came to be charged with bastardy, murder, and rape, and the family of Carrolls who kept their Catholic faith and amassed great wealth, but still found their good name sullied with allegations of self-dealing, usury, breach of trust, illegitimacy, and slave-driving.

The essay argues that the Carrolls succeeded while Calverts failed because (in today's parlance) they had a better "business plan." The Calverts clung to their feudal rights while the Carrolls diversified their investments and plunged into the market economy. Capitalism trumped feudalism.

The essay casts doubts on the sincerity of the revolution rhetoric of "freedom." The Carroll family motto was "Anywhere So Long as there be Freedom" and indisputably they were seekers after the religious freedom to keep their Catholic faith. But this narrative suggests, at least from viewpoint of the Carroll family, that money not freedom was the driving engine of the American

${ }^{13}$ John E. HOWARD \& JAMES CARROLl, JR., TO THE LANDHOLDERS OF THE STATE OF MARYLAND 1-5 (Baltimore 1825). 
Revolution. The Carrolls were Maryland's largest holders of slaves and indentured servants, and they had no intent of relinquishing them. Captive labor was an important source of their wealth and a necessary factor of production on their agricultural plantations. The Carrolls only hesitantly took the risk of revolution and popular government to be rid of the British restrictions on free trade, to escape perpetual debts owed the lord proprietors, and to increase the supply of currencies of exchange. They sought more and better money.

Finally the essay debunks the notion that "inviolable" and "sacred" rights of property in land that have existed as a matter of natural law since "time immemorial." It demonstrates that land only was transformed into a marketable commodity through "an act of naked judicial legislation" in the sixteenth century. The courts created a "legal fiction" that nullified family "restraints on alienation" and changed feudal estates into what we know today as "property." The United States Supreme Court by refusing to consider Cassell v. Carroll on the merits rendered a default judgment in favor of judicial activism and freedom of alienation. ${ }^{14}$

\section{MARYLAND'S FOUNDING FAMILIES}

The Calverts were quite literally the first family of Maryland. Cecil Calvert had been present at its creation. In 1623 King James I had dubbed Cecil's father, George Calvert, the Baron of Baltimore and upon George's death in 1632 this hereditary title passed to Cecil who in that same year was granted a royal charter to the New World colony of Maryland. This charter gave the Second Lord Baltimore and the first Lord Proprietor of Maryland all the feudal privileges of the monarch.

Proprietorship allowed the Baron of Baltimore and his heirs to "assigne, aliene, grant, demise or enfeoff" the lands of Maryland "to persons . . . willing to take of purchase the same ... subject to such . . rents as shall seeme fit." The Barons were further granted license "to erect any parcels of land within the Province ... into Mannors" with respect to which they might subinfeudate tenements subject to their superior lordship forever. The Calverts were thus empowered to create their own feudal fiefdom in the wilderness. ${ }^{15}$

The seignory granted by the Charter included "ample ... Royall rights, and franchises of what kind soever. . . To have, exercise, use and enjoy the same, as

${ }^{14}$ See Joseph William Singer, Introduction to Property "“The Alienation Dilemma" $\S 1.3 .4$ (2001).

${ }^{15}$ MD. CHARTER 21-22 (1632). 
amply as any Bishop ... within the Palatine of Durham ... hath . . enjoyed." The Calverts were thereby intended to have royal rights as fully as the King had in his palace (in Palatio) - sovereign powers of the highest order. The Lords Baltimore were further authorized "for the good and happy government of the said Province, to ... enact ... Lawes ... with the advise, assent and approbation of the Free-men of the said Province" and to "enjoy . . Customs and Subsidies."16

Charles Carroll was a third generation Marylander. He was the namesake of his father and grandfather before him. He was the very same Charles Carroll of Carrollton who in 1776 had signed the Declaration of Independence with a flourish, and who now in 1823 found himself at age 86 the last living founding father. ${ }^{17}$

The three successive generations of Charles Carrolls had amassed a spectacular fortune worth approximately $\$ 1.6$ million. ${ }^{18}$ Charles Carroll, the Settler (1661-1720) had acquired his capital the old-fashioned way-he had married for money and then, while working for his well-placed father-in-law, had been an inside trader in the burgeoning land market. His son Charles Carroll of Annapolis (1702-1782) had diversified the family land holdings with investments in slaves, loans, mortgages and the Baltimore Iron Works. And the grandson, Charles Carroll of Carrollton (1737-1832), had secured the family fortune by astutely deciding to be a revolutionist rather than a loyalist during the War for American Independence. ${ }^{19}$

\section{The Calvert Family 1632-1715}

\footnotetext{
${ }^{16}$ Md. Charter 5, 9, 20 (1632); Lewis MAYer, Ground RENTS In MARYLAND 9-13 (Baltimore, Cushings \& Bailey 1883).

${ }^{17}$ Sally Mason, Charles Carroll and his Family, 1688-1832, in BALTIMORE Museum OF ART, Anywhere So long as there Be Freedom, Charles Carroll of CARrollton, His Family AND HIS MARYLAND 9 (An Exhibition and Catalogue 1975).

${ }^{18} \$ 1.6$ million in 1825 would have the purchasing power of \$29.6 Million in the year 2003. See John J. McCusker, Economic History Services, Comparing the Purchasing Power of Money in the United States (or Colonies) from 1665 to 2003 (2004), at http://www.eh.net/hmit/ppowerusd/.

${ }^{19}$ Ronald Hoffman, Princes of Ireland, Planters of Maryland: A CARroll SaGa, 15001782 (2000); Edward C. Papenfuse, Charles Carroll of Carrollton: English Aristocrat in an American Setting, in BALTIMORE Museum of ART, ANYWHERE So LONG AS THERE BE FrEEDOM, Charles Carroll of Carrollton, His Family and His Maryland 35, at 43-57 (An Exhibition and Catalogue 1975). Baltimore merchant Robert Oliver and Philadelphia Banker Stephen Girard (\$8-10 million) were among those with greater wealth.
} 


\section{Cecil Calvert, 2nd Lord Baltimore}

Maryland's 1632 Charter had vested the Barons of Baltimore with proprietary rights. Cecil Calvert, the first Lord Proprietor looked to take his profit from the soil. He promoted settlement by offering "adventurers" land patents of "hundreds" in return for the transportation of themselves and their laborers who undertook "plantation." Later proprietors demanded a purchase price called "caution money," payable in tobacco or pounds sterling in return for the patents. When granting patents however, Cecil and his successors only passed title by way of "subinfeudation." After the grants, the "takers-up" continued to owe the Calvert family an annual quit-rent payable in perpetuity. In 1671 the annual quit rents were set at 4 shillings per hundred acres. ${ }^{20}$

Cecil Calvert also started the policy of reserving large parcels of land to be "erected into proprietary manors" for. These were held by the Baltimore barony in the anticipation of increased land values, and in the meantime leased for cultivation in smaller holdings to long-term tenants. ${ }^{21}$

Hence the first Lord Proprietor had undertaken to create a fiefdom in the wilderness. The quit-rents provided a perpetual source of income that would be passed on from the current generation to the eldest male heir in the next. The proprietary lands would serve as the foundation of the family's power, status and wealth. In practice, however, land patents were handled irregularly and few proprietary manors were created. Tens of thousands of vacant acres were still up for grabs. Only after Charles Calvert had succeeded his father in 1675 to become the 3rd Lord Baltimore was a more formal land council established with Charles' cousin Henry Darnall serving as one of the four members. ${ }^{22}$

\section{Charles Calvert, 3rd Lord Baltimore}

During Charles Calvert's tenure as the third Lord Baltimore major changes took place in the governance of Maryland. In addition to proprietary rights, Maryland's 1632 Charter had vested the hereditary line of Baltimore Barons with seigniory. As seigniors the Lords of Baltimore had "all . . ample rights,

\footnotetext{
${ }^{20}$ JOHN KILTY, The LANDHOLDER's Assistant, AND LAND-OFFICE GuIDE 64 (Baltimore, G. Dobbin \& Murphy 1808); Clarence P. Gould, The LAND SySTEM In MARYLAND 1725-1765, at 9-10 (1913).

${ }^{21}$ Clarence P. Gould, The Land System in Maryland 1725-1765, at 89-101 (1913).

22 John KILTY, The LANDHOLDER's Assistant, AND LAND-OfFICE GUIDE 127-28, 162 (Baltimore, G. Dobbin \& Murphy 1808).
} 
Jurisdictions, Priviledges, Prerogatives, Royalties, . . . rights, and franchises . . . . saving alwayes, the faith and allegeance, and Soveraigne dominion due to Us, Our Heires and Successors ... . Kings of England." They were granted "full, and absolute power . . . for the good and happy government of the said Province, to . . . enact ... any Lawes whatsoever ... with the advise, assent, and approbation of the Free-men of the said Province, or . . . their delegates or deputies."

In England in 1689 the new Protestant monarchs, William and Mary, deposed the Catholic James II in what came to be called the "Glorious Revolution." In its aftermath, the Crown in 1692 declared Maryland a royal colony. Charles Calvert the $3^{\text {rd }}$ Lord Baltimore was divested of his seigniory. No longer would he and his heirs be able impose taxes or pass laws. He was permitted, however, to retain his proprietary lands and his quit-rents. ${ }^{24}$

Charles Calvert the $3^{\text {rd }}$ Lord Baltimore was left with the task of making sure that the Baltimore's proprietorship would be kept in the family-forever. The 1632 Maryland Charter had granted all lands within the limits of the province to Charles' father, Cecil Calvert "the said now Lord Baltemore, his heires and assignes." As the eldest son in the next generation Charles had inherited the Maryland lands under the English inheritance principal of primogeniture. But since 1660 primogeniture was purely optional and could be defeated by a deed or will to an outsider. Charles Calvert the $3^{\text {rd }}$ Lord Baltimore undertook to make sure the proprietorship stayed in the family. In 1698 he executed a deed by which he settled the province of Maryland on himself for life, with the remainder to go to his son Benedict for life, with a remainder to "male heirs of the body" of Benedict. This estate of fee tail male was intended to assure that the Baltimore proprietary lands and quit-rents would pass down to the family's male descendants, generation after generation. Subsequent Barons of Baltimore were intended to be foreclosed from making a transfer to an outsider. ${ }^{25}$

In 1713 when Charles the $3^{\text {rd }}$ Lord Baltimore was in his eighty-third year and death seemed close at hand, his son and heir, Benedict Calvert undertook to improve the family's station. He reckoned that the family's Catholicism was all that prevented the restoration of its sovereignty over Maryland. In anticipation of

\footnotetext{
${ }^{23}$ Md. ChARTER 5-10 (1632).

${ }^{24}$ Robert J. Brugger, Maryland, A Middle Temperament, 1634-1980, at 39-40, 800 (1988).

${ }^{25}$ A.W.B. Simpson, A History of THE LAND LAW 284 (2d ed. 1986); Cassell v. Carroll, 24 U.S. (11 Wheaton) 134, 136 (1826); John E. HOWARD \& JAMES CARROLL, JR., TO THE LANDHOLDERS OF THE STATE OF MARYLAND 7 (Baltimore 1825).
} 
his succession to the lordship he embraced the Protestant faith. His father the $3^{\text {rd }}$ Lord Baltimore was outraged but did nothing about it before death in 1715 made Benedict Leonard the $4^{\text {th }}$ Lord Baltimore. ${ }^{26}$

Benedict's scheme had worked, but not long to his advantage. Within weeks after successfully petitioning the Crown for the return his governing power over Maryland the $4^{\text {th }}$ Lord Baltimore died in 1715. His sixteen-year-old son and heir, Charles, became the $5^{\text {th }}$ Lord Baltimore. ${ }^{27}$

\section{The Carroll Family (1688-1761)}

\section{Charles Carroll the Settler}

Charles Carroll arrived in Maryland in 1688 expecting to receive a ministerial post from his Catholic co-religionist the $3^{\text {rd }}$ Lord Baltimore. He discovered on his arrival that the Protestant upstarts had overthrown the proprietary officials, and that Lord Charles had no governmental commission to offer him.

Charles Carroll the Settler, who had been trained in law, found work in the courts of chancery. In 1689 after serving as the executor of an estate consisting of nearly $£ 550$ sterling and 2000 acres of land, he married the rich widow, Martha Ridgely Underwood. The marriage, just six months after the decedent's death, proved as short-lived as the bereavement. Martha died in childbirth in 1690, leaving the Charles as the administrator of her assets.

In 1694 the Settler remarried. His second bride was fifteen-year-old Mary Darnall, the daughter of Henry Darnall, the absentee Lord Baltimore's land agent. Darnall bestowed on his new son-in-law a grant of a grant of 1,400 acres and an appointment as clerk in the Proprietor's land office. ${ }^{28}$

The Settler divided his efforts between the vociferous defense of the Calvert's rights to revenues, and to the creation of a landed estate for his own family. Twice he was sent to jail for seditious speeches in derogation of the royal government, but on each occasion after he reentered colonial society he continued

\footnotetext{
${ }^{26}$ Ronald Hoffman, Princes of Ireland, Planters of Maryland: A CARroll Saga, 15001782, at 79-80 (2000).

${ }^{27}$ Ronald Hoffman, Princes of Ireland, Planters of Maryland: A Carroll Saga, 15001782, at 79-80 (2000).

${ }^{28}$ Ronald HofFman, Princes of Ireland, Planters of Maryland: A CARroll SaGa, 15001782 , at 64-72 (2000).
} 
his vituperative ways. While parceling out vacant land from the proprietor's land office he also traded on his own account. ${ }^{29}$

The land office procedures for acquisition of parcels of proprietary lands followed two steps. The applicant would first request a warrant for a specific parcel and then after the purchase price (the caution money) was agreed upon and paid, Henry Darnall, Lord Baltimore's agent, would grant the applicant a patent and title would pass. Adventurers soon recognized that a warrant was in effect an option to purchase with respect to which neither caution money or quit-rents need be paid, unless and until it was exercised. Rampant speculation in warrants significantly reduced the Proprietor's revenue. ${ }^{30}$

When accumulating his own landed estate, Charles Carroll the Settler took the advantage, first acquiring the warrants and then only taking title after the land was ripe for development. By 1700 the he had acquired warrants for some 12,000acres but patented only 3,900. Among his warrants was a 7,000 acre parcel on the border of Baltimore and Anne Arundel counties. When the Settler secured a patent for the parcel and a 3000 acre addition in 1711, Lord Baltimore extended him the unique privilege of paying no quit-rents until his infant son reached the age of majority. This parcel was to constitute Doughoregan Manor, the family's principal dwelling plantation.

The Settler continued to accumulate land into the new century. He concentrated his acquisitions in the vicinity of Annapolis and eventually came to own most of the west side of town. Another noteworthy purchase was a 550 acre parcel in Baltimore County to the north of the basin in the Patapsco River which had originally been a part of the patent for Todd's Range. ${ }^{31}$

Henry Darnall, Lord Baltimore's Maryland agent also had been acquiring proprietary land. When died in 1711 he left an estate consisting of 18,000 acres of land. Charles Carroll the Settler succeeded his father-in-law as Lord Baltimore's agent. Any questions as to a breach of trust in the proprietary land office were

\footnotetext{
${ }^{29}$ Ronald Hoffman, Princes of Ireland, Planters of Maryland: A Carroll Saga, 15001782, at 45-46 (2000).

${ }^{30}$ Clarence P. Gould, The Land System in MARYland 1725-1765, at 15-17 (1913).

${ }^{31}$ Ronald Hoffman, Princes of Ireland, Planters of Maryland: A CARroll Saga, 15001782, at 71-73 (2000); Garrett Power, Parceling Out Land in the Vicinity of Baltimore:16321796, Part I, 87 MARYLAND Historical MAGaZine 453, 458 (1992).
} 
settled when Calvert explicitly exonerated both Darnall and Carroll from liability for past excesses or self-dealings. ${ }^{32}$

The Settler continued his efforts to increase his private land holdings. By the time of his death in 1720 he owned 48,000 acres and was the largest landowner in Maryland. He also possessed a warrant to 10,000 acres of western land between the Potomac and Monocacy Rivers that would one day be granted to his grandson and known as Carrollton. ${ }^{33}$

The Settler's lordly pretensions can be seen in his styling of the family's 10,000 acre home as Doughoregan Manor. However there was no pretense with respect to his wealth. His land holdings were worth an estimated at $£ 20,000$ and the value of his 112 slaves at $£ 2,000$. These sums, when added to his portfolio of outstanding mortgage loans of $£ 2,500$, made him perhaps the richest man in Maryland. ${ }^{34}$

\section{Charles Carroll of Annapolis}

Charles Carroll the Settler's death in 1720 posed the question as to what would become of the family's wealth. The Settler's surviving family consisted of a wife and four minor children - two daughters and 17- and 12-year-old sons, Charles and Daniel. Charles, the eldest and heir at law, undertook to manage the family inheritance.

During the remaining three years of his minority Young Charles was guided in financial matters by his godfather and cousin James Carroll. Charles was a quick study. Upon achieving majority in 1723 he was ready and willing to manage the family fortune with a vengeance. Emblematic of his coming of age was his construction of a solid brick house on the Annapolis waterfront. Thereafter he came to be known as Charles Carroll of Annapolis.

The Settler's will specifically bequeathed most of his landed estate to his sons Charles and Daniel "to be equally divided, share and share alike." By tacit

\footnotetext{
${ }^{32}$ Robert J. Brugger, Maryland, A Middle Temperament, 1634-1980, at 55 (1988); JohN KILTY, The LANDHOLDER's Assistant, AND LAND-OFFICE GUIDE 128-132 (Baltimore, G. Dobbin \& Murphy 1808).

${ }^{33}$ Ronald HofFman, Princes of Ireland, Planters of Maryland: A CARroll SaGa, 15001782, at 67-76 (2000).

${ }^{34}$ Clarence P. Gould, The Land System in Maryland 1725-1765, at 89-90 (1913); Ronald Hoffman, Princes of Ireland, Planters of MARYland: A CARroll SAGA, 1500-1782, at $67-$ 76 (2000).
} 
agreement Charles of Annapolis undertook active management. And from the beginning young Charles of Annapolis seemed up to the task. For example, in 1723 he exercised the warrant the Settler held on 10,000 acres of western frontier land and took up a patent to Carrollton Manor. Charles' trusteeship over family lands worked amicably enough as Daniel married and busied himself with his wife and three children. ${ }^{35}$

At first the Carroll estate was shared by a large family, but not for long. Between 1730 and 1742 Charles' brother Daniel, two sisters and mother all died. The Annapolitan found himself and Daniel's minor children the Settler's only living issue. On Charles Carroll of Annapolis alone had fallen the tasks of aggrandizing the Carroll fortune and passing it on to a suitable heir. ${ }^{36}$

Carroll of Annapolis's strategy involved diversification of the family investments. He by and large stopped speculating in land and sold off some of the existing holdings. For example, in 1729 he petitioned the General Assembly for permission to erect a town on his 550 acre Todd's Range tract, and when Baltimore Town was established he parceled it out as building lots.

He expanded his father's money-lending operations until he became the colony's largest lender. He partnered in the establishment of the Baltimore Iron Works. He increased the cultivation of grain and livestock as well as tobacco on the on the family's several plantations (principally Doughoregan and Carrollton) with labor provided by a combination of slaves and tenants imported from Ireland and Germany. These leaseholders were "tenants at will" who were subject to Carroll's preemptory removal. ${ }^{37}$

His strategy for producing a suitable heir was less orthodox. In the 1730's Charles Carroll of Annapolis and Elizabeth Brooke took up cohabitation. Even though Miss Brooke would have been a suitable spouse in terms of both station

\footnotetext{
35 Ronald Hoffman, Princes of Ireland, Planters of Maryland: A CARroll Saga, 15001782, at 89-126 (2000); Sally Mason, Charles Carroll and his Family, 1688-1832, in Baltimore Museum of Art, ANyWhere So long as there Be Freedom, Charles Carroll OF CARROLLTON, His FAMILY AND His MARYLAND 9, 16 (An Exhibition and Catalogue 1975).

${ }^{36}$ Ronald Hoffman, Princes of Ireland, Planters of Maryland: A CARroll Saga, 15001782, at 108 (2000).

${ }^{37}$ Ronald Hoffman, Princes of Ireland, Planters of Maryland: A CARroll Saga, 15001782, at 109-117 (2000); Edward C. Papenfuse, Charles Carroll of Carrollton: English Aristocrat in an American Setting, in BALTIMORE MuSEum OF ART, ANYWHERE So LONG AS THere Be Freedom, Charles Carroll of CARrollton, His FAmily AND His Maryland 35, at 48-49 (An Exhibition and Catalogue 1975).
} 
and religion they did not marry. In 1737 this extra-marital union produced a sonyet another Charles Carroll. Young Charley was openly recognized as his father's son and given a first-class European education, but he remained illegitimate and without entitlement.

One can only conjecture as to why Charles Carroll of Annapolis denied Elizabeth the benefit of clergy and rendered his son a bastard. The best guess is that he was consumed by a dynastic urge. Recently reminded of the frailty of human life, he took precautions to be sure he would have a suitable son and heir. Since his liaison with Elizabeth had produced but one son, the Annapolitan kept open the option, in the event that young Charley were to die or disgrace himself, of finding another wife and siring another son to carry on the family name. ${ }^{38}$

In 1757 young Charley was in his twentieth year only months from majority. It was time for Charles Carroll of Annapolis put his affairs in order. After entering into a prenuptial agreement whereby Elizabeth waived all claims on his estate, he and she were married.

Subsequently a will was executed making Charley his heir. After receiving a grant to the 12,000 acre Carrollton Manor, young Charley could distinguish himself as Charles Carroll of Carrollton. ${ }^{39}$

Charles Carroll of Annapolis also had less agreeable family matters to attend. Since his brother Daniel's premature death in 1734 he had been managing Daniel's lands for the benefit of his nephew, Daniel's son and heir. In 1757 uncle and nephew agreed upon a division on lands whereby Charles took Doughoregan and Carrollton while the nephew took other lesser plantations. But when the nephew received the advice of others and had second thoughts, Charles of Annapolis refused to rescind the deal. Daniel made allegations of fraud. A subsequent accounting revealed that during his twenty-three year trusteeship

\footnotetext{
${ }^{38}$ Sally Mason, Charles Carroll and his Family, 1688-1832, in BALTIMORE Museum OF ART, Anywhere So long as there Be Freedom, Charles Carroll of Carrollton, His Family AND His MARYLAND 9, 16-17 (An Exhibition and Catalogue 1975).; RonALD HofFMAN, PRINCES OF IREland, Planters of MARYland: A CARRoll SAGA, 1500-1782, at 131-142, 398-401 (2000).

${ }^{39}$ Sally Mason, Charles Carroll and his Family, 1688-1832, in BALTIMORE MUSEUM OF ART, ANyWhere So long as there Be Freedom, Charles CARroll of CARrollton, His Family AND His MARYLAND 9, at 16-17 (An Exhibition and Catalogue 1975).
} 
Charles had charged a 5\% commission on every transaction. Charles for his part seemed unable to comprehend how he could be expected to provide services without charging all the fees that the law allowed. The dispute was submitted to private arbitration and after years of acrimony Charles of Annapolis was ordered to pay $£ 1,500 .^{40}$

The picture this paints of Charles Carroll of Annapolis's character and soul is not a pretty one. He seems a selfish, status-seeking miser. But there is no gainsaying his success in building the family fortune. In 1756 he bragged, "[ $t]$ here is but one Man in the Province whose Fortune equals mine." He calculated his net worth at $£ 88,000$ sterling. $^{41}$

\section{The Calvert Family (1715-1771)}

The scheme of Benedict, the $4^{\text {th }}$ Lord Baltimore had worked. Maryland was no longer a Royal Colony. By forsaking the Catholic faith and embracing Protestantism he had convinced the Crown to restore seigniory to the Baltimore Barony. But then in 1715 Benedict precipitously died making his son, young Charles Calvert, the $5^{\text {th }}$ Lord Baltimore.

From his residence in England the young Charles Calvert, the restored Lord Proprietor, faced several dilemmas. First, how should he share his powers of governance with the Maryland Assembly, which during the Royal years had come to exercise significant legislative prerogatives? Second, how could he collect revenue from Maryland's recalcitrant freemen? And third, how could he assure that the Calvert dynasty would continue after his death?

\section{Charles Calvert, the 5th Lord Baltimore (1715-1751)}

Much of the conflict between the proprietor and the Assembly related to revenues. No one disputed the proprietor's right to a purchase price for patents of proprietary lands (called caution money) but the actual collection of quit-rents was a persistent problem. There was no effective procedure through which the proprietor's agents could each year force payment of the sums due from the province's far-flung plantation aristocrats.

\footnotetext{
${ }^{40}$ Ronald Hoffman, Princes of Ireland, Planters of Maryland: A Carroll Saga, 15001782, at 123-130, 218-219 (2000).

${ }^{41}$ Ronald Hoffman, Princes of Ireland, Planters of Maryland: A Carroll Saga, 15001782, at 122 (2000).
} 
Since colonial times the annual quit-rents had been set at 4 shillings for every one hundred acres of land. (The proprietor had made a short-lived effort to raise the rate on new patents to 10 shilling per acre but soon backed off when his land sales dwindled). The amount of the quit-rents was measured in pounds sterling, but the media of exchange (guineas, shillings and crowns) were in short supply. Due to the deficit in the balance of trade, currency inevitably ended up back in England. Gold and silver were likewise in scarce supply, thereby forcing the proprietor to accept payment in tobacco and grain, and raising persistent questions as to the commodity's exchange value.

During the Royal period from 1689 to 1715 , the proprietors had reluctantly accepted an export duty of 1 shilling per hogshead of tobacco in lieu of quit-rents. By shifting the burden of payment from planters to traders the exchange rates were fixed and collection was facilitated. And in 1715 with his seigniory restored the $5^{\text {th }}$ Lord Calvert convinced the Assembly to increase the export duty to 2 shillings per hogshead. But then over the next decade the popular suspicion grew that the proprietor's revenue was excessive. ${ }^{42}$

In 1733 the Assembly repealed the export duty and the quit-rent system was reinstated. The proprietor once again faced the task of collecting his quit- rents. The $5^{\text {th }}$ Lord Baltimore answered the challenge by establishing rent rolls for each county and by appointing collectors called "rent farmers." The rent farmer received a commission from 20 to $30 \%{ }^{43}$

By the beginning of the American Revolution annual quit-rents totaled over $£ 8,000$. It is hard to determine just how economically burdensome the quit-rents were on the landowners of Maryland. The amount of the quit-rent (4 shillings per acre) was assessed according to the acreage of the land, not according to the value of the land. When compared with market value, rents were cheap for expensive land but expensive for cheap land. It seems likely, however, that Maryland's eighteenth century aristocrats who had amassed their fortunes in land (e.g. Carrolls, Lloyds, Howards, Dulanys, Bennetts, Keys, Dorseys) were paying Lord

\footnotetext{
${ }^{42}$ Robert J. Brugger, Maryland, A Middle Temperament, 1634-1980, at 88 (1988); Beverly W. Bond, The Quit Rent in Maryland, 5 MARYLAND HistoriCAL MAGAZINE 350, 35053 (1910); Clarence P. Gould, The Land System in Maryland 1725-1765, at 19-33, 33, 51 (1913).

${ }^{43}$ Beverly W. Bond, The Quit Rent in Maryland, 5 Maryland Historical Magazine 350 (1910); Clarence P. Gould, The Land System in Maryland 1725-1765, at 19-33, 33, 51 (1913).
} 
Baltimore a significant annual tribute. One rough extrapolation put the average rate of exaction at $1 \%$ of the land's value. ${ }^{44}$

Charles Calvert the $5^{\text {th }}$ Lord Baltimore had one other lifetime preoccupation. How could he assure for generations yet to come that the Province of Maryland would remain in the Calvert family. Charles' grandfather had in 1698 placed the proprietorship in an estate of fee tail male thereby limiting descent to male Calvert descendants, but if the male blood line of Calverts was to run out, ownership of the province of Maryland would be in question. In 1730, Charles the $5^{\text {th }}$ Lord Baltimore undertook to settle the doubt by executing a deed of strict settlement that restated the fee tail male estate and additionally provided that, should the male blood line expire, the "remainder" should pass to "Charles in fee." Charles' deed thereby asserted his entitlement to designate ownership of the province of Maryland in the event that any future time there ceased to be "lawfully begotten" male descendants. In that event Charles' will could specify the alternative owner.

In 1750 Charles the $5^{\text {th }}$ Lord Baltimore executed his will. Therein he specified that if his son and heir Frederick died without a "lawfully begotten" male issue, then the remainder should pass to Charles' daughter Louisa. (If Louisa predeceased Frederick her younger sister Caroline was designated as the alternative remainderman) Charles' will further specified that his daughter Louisa would have final disposition over the province of Maryland if the male line of Calverts died out. ${ }^{45}$

Charles Calvert the $5^{\text {th }}$ Lord Baltimore died in 1751 survived by his son Frederick and his daughters Louisa and Caroline. Frederick became the $6^{\text {th }}$ Lord Baltimore and took title to the province of Maryland. History has nothing good to say about Frederick. According to all reports he was a spendthrift and a scoundrel and most likely both a murderer and a rapist.

His father's will had devised the province of Maryland in trust for the use of Frederick for life, with the remainder to his sons in tail male. Frederick's 1753 marriage settlement with Lady Diana Edgerton further subjected the province to a trust for her lifetime benefit. But Frederick was soon estranged from his wife, greedy for more money. He undertook to capture absolute ownership of Maryland. In 1758 the Parliament of England refused his request for an enactment cutting off

\footnotetext{
${ }^{44}$ Beverly W. Bond, The Quit Rent in Maryland, 5 Maryland Historical Magazine 350, 358 (1910); Clarence P. Gould, The LAND System In MARYLAND 1725-1765, at 54-55, 82 (1913). ${ }^{45}$ Cassell v. Carroll, 24 U.S. (11 Wheaton) 134, 136-37 (1826).
} 
the entail and vesting him with an estate in fee simple absolute. But Frederick had more success in defeating his wife's jointure. In that same year Lady Diana went out for an airing with her husband and "died from a hurt she received by a fall out of a Phaeton" carriage. The circumstances created the suspicion of homicide but charges against his Lordship were never brought. That same year Henry Harford was born the illegitimate son of Lord Frederick and Hester Wheland. ${ }^{46}$

Although still only a life tenant Frederick was receiving substantial income from the province of Maryland. The caution money the Land Office received in return for patents to vacant land when added to quit-rents and tonnage duties provided revenues of over $£ 10,000$ annually. Moreover Frederick had inherited from his father over twenty manors constituting of almost 200,000 acres of prime land that the lord proprietors had reserved. ${ }^{47}$

In the late 1760 's provincial disaffection with the Calverts' proprietary establishment was on the rise. The Assembly fulminated over the fees and quitrents that provincial Marylanders were forced to pay an absentee lord proprietor. In 1769 Frederick appointed his affable brother-in-law, Sir Robert Eden his new governor of Maryland in an effort to quiet the discord. ${ }^{48}$

Lord Frederick was likewise not content with his economic status quo. He was dissatisfied with the $£ 8,000$ in quit-rent income he received each year as the tenant in tail. ${ }^{49}$ He wanted the unlimited freedom to alienate the entirety of his seigniory and proprietary rights in Province of Maryland. He undertook to break the entailment that his great grandfather and father had placed on the province.

In his efforts to dock the entail Frederick faced a legal conundrum. Fee tail estates limiting descent to lineal heirs had been an accepted under English land law since the Statute de Donis Conditionalibus in 1285. But in the years since the King's courts had come to recognize the economic and social disadvantages of such "dead hand" rule. These activist English judges in an act of "naked judicial legislation" approved a fiction known as "common recovery" - a collusive court decree awarding the tenant in tail a fee simple estate and thereby cutting off the

\footnotetext{
${ }^{46}$ Charles Browning, An Appeal to the Citizens of Maryland 3 (Baltimore, T.R. Lusby 1821).

${ }^{47}$ Vera A. Foster Rollo, The Proprietorship of MAryland: A Documented Account 38 (1989).

${ }^{48}$ Robert J. Brugger, Maryland, A Middle Temperament, 1634-1980, at 108-09 (1988).

${ }^{49}$ Beverly W. Bond, The Quit Rent in Maryland, 5 MARYLAND HistoriCAL Magazine 350, 358 (1910).
} 
rights of his issue. ${ }^{50}$ But this fiction might not to be open to Frederick. He was intent upon capturing for himself alone not only proprietary rights (including the entitlement to quit-rents) but also seigniory rights in the Province of Maryland, and all the appurtenances thereto (including rights to make laws, appoint officials and to exercise final political and judicial authority). There were no precedents to support the jurisdiction of Frederick's courts to issue a collusive decree in Frederick's favor that terminated the hereditary proprietorship. ${ }^{51}$

Frederick attempted to cut off the rights of subsequent Calvert heirs by means of straw deeds of lease and release. In 1761 he nominally transferred the Province of Maryland to Thomas Bennett and William Sharpe. Just six months later these strawmen, "released" the province to Frederick Calvert, the $6^{\text {th }}$ Lord Baltimore for life, subject to Frederick's unlimited power of appointment by deed or will. Thereafter Lord Frederick asserted that this settlement necessarily provided him with an unlimited estate in fee simple "there being no other established method for barring entails" in Maryland. ${ }^{52}$

In 1767 Frederick took the additional step of seeking a collusive common recovery. This sham procedure involved a fictitious law suit and had been accepted by English courts and Parliament as a means for disentailing estates in Great Britain. But it remained uncertain as to whether the Maryland proprietor could prevail in a collusive action in his own Maryland provincial courts. ${ }^{53}$

A year later Frederick was tried for the rape of the respectable young keeper of a millinery shop. The evidence tended to show that Lord Baltimore had one of his servants abduct Mistress Sarah Woodstock who was then held in his mansion for several days until she consented to "seduction." 54 Public opinion found Frederick guilty, but the jury acquitted finding that Mistress Woodstock had

\footnotetext{
${ }^{50}$ A.W.B. SimPSON, A HiSTORY OF THE LAND LAW 81-102, 129-137 (2d ed. 1986).

${ }^{51}$ See Calvert's Lessee v. Eden, 2 H. \& McH. 279, 369 (Md. 1789).

${ }^{52}$ See Calvert's Lessee v. Eden, 2 H. \& McH. 279, 372 (Md. 1789).

${ }^{53}$ Calvert's Lessee v. Eden, 2 H. \& McH. 279, 286-287 (Md. 1789); Harford v. Browning, Trinity Term, Geo. 3 B.R., June 27, 1775, repinted in Cassell v. Carroll, 24 U.S. (11 Wheaton) 134, 153-71 (1826); GEORGE C. BRODRICK, ENGLiSH LAND AND ENGLISH LANDLORDS 23 (Farnborough, Eng., Gregg International 1968) (1881).

54 The TRIAL of FredericK CALVERT, EsQ; BARON OF BALTIMORE, IN THE Kingdom OF IRELAND: For A RAPE ON THE BODY OF SARAH WOODCOCK (John Mein, pub., London (Boston) 1768), microformed on Early American imprints, 1st series; no. 10919 (Readex, Newsbank, Inc.).
} 
vacillated in her attempts to escape. In disgrace the Sixth Lord Baltimore repaired to Naples where he lived for the rest of his life, never having visited Maryland. ${ }^{55}$

In 1771 Frederick Calvert the $6^{\text {th }}$ Lord Baltimore died without any "lawfully begotten" sons or daughters, but survived by his sisters, Louisa and Caroline. In that event his father Charles' 1750 will specified that the Province of Maryland was to pass to "Louisa, my eldest daughter, her heirs and assigns forever." In disregard Louisa's rights Frederick devised the Province of Maryland and to all of its appurtenances to his illegitimate son Henry Harford. Whether the straw transactions in 1761 or the common recovery in 1767 had effectively barred Louisa's residual rights under her father's will remained an unanswered question. ${ }^{56}$

When Frederick died in 1771 his brother-in-law Robert Eden (the husband of Caroline Calvert Eden) was serving as his governor of Maryland. The guardian of 13-year-old Henry Harford instructed Eden to continue governing Maryland and after a two year delay notified the Assembly that Frederick was dead and that that young Harford was the new proprietor. The Maryland Assembly readily accepted Harford and in 1773 created Harford County in his honor. ${ }^{57}$

Other aspects of Eden's administration were more conflicted. Maryland leaders objected to the proprietor's sovereignty in general and to increased fees in particular. Charles Carroll of Carrolton challenged such "prerogative power" in the press. Revolution was in the wind. ${ }^{58}$

Meanwhile in England, John Browning brought suit in the English Court of Chancery on behalf of his wife Louisa in an effort to recover possession of the Province of Maryland from Henry Harford. Browning was joined by Sir Robert Eden, on behalf of his wife Caroline (Louisa and Caroline being the heirs at law of Frederick Calvert the $6^{\text {th }}$ Lord Baltimore). With this surprising turn of events Eden,

\footnotetext{
55 The Trial of Frederick CALVERT, EsQ; BARON OF BALtimore, In THE Kingdom OF IRELAND: FoR A RAPE ON THE BODY OF SARAH WOODCOCK (John Mein, pub., London (Boston) 1768), microformed on Early American imprints, 1st series; no. 10919 (Readex, Newsbank, Inc.); Vera A. Foster Rollo, The Proprietorship of MARYland: A DoCUMENTED ACCOUnT 45, 66, 67 (1989).

${ }^{56}$ Harford v. Browning, 15 Geo. 3 B.R., June 27, 1775, reprinted in Cassell v. Carroll, 24 U.S. (11 Wheaton) 134, 153-71 (1826).

57 Vera A. Foster Rollo, The Proprietorship of Maryland: A Documented AcCount 5152 (1989).

58 Vera A. Foster Rollo, The Proprietorship of Maryland: A Documented Account 5153 (1989).
} 
the governor of the province of Maryland, found himself suing the estate of the Maryland proprietor whom he had served. ${ }^{59}$

The case was sent to the Court of Kings Bench which heard arguments in 1775. Lord Mansfield the presiding judge was unwilling to make up his mind. In his words:

The questions in this case are new, and of great difficulty .... I do not know of any litigated case before the present, in which the question has been, whether a seigniory like that of Maryland can be aliened or devised .... Another thing quite new, is the question as to barring the entail ...

He ordered the case to "stand for argument a second time." 60

The American Revolution intervened and Eden was deposed of his Maryland governorship before the case was settled out of court in 1780. An agreement then was entered into between Henry Harford and John Browning (the husband of Louisa Browning) and Sir Robert Eden (the husband of Caroline Eden) Since Louisa was a lunatic and a ward of Chancery she was also represented by the guardian of her real and personal estate. ${ }^{61}$

The settlement made an absolute cession of the province of Maryland, its revenues and quit-rents, to Harford and his heirs, upon payment of $£ 22,000$ to John and Louisa Browning and $£ 17,500$ to Sir Robert Eden and his wife Caroline. The settlement was approved by the British Parliament and the Crown.

\section{The Carroll family (1715-1782)}

Charles Carroll of Annapolis sent his young son off to be educated by the French Jesuits in 1749. Young Charley met his father's expectations as a scholar and a gentleman and was rewarded in 1761 by a will making him his father's heir.

\footnotetext{
${ }^{59}$ Harford v. Browning, 15 Geo. 3 B.R., June 27, 1775, reprinted in Cassell v. Carroll, 24 U.S. (11 Wheaton) 134, 153-71 (1826).

${ }^{60}$ Harford v. Browning, 15 Geo. 3 B.R., June 27, 1775, reprinted in Cassell v. Carroll, 24 U.S. (11 Wheaton) 134, 170-71 (1826).

${ }^{61}$ See Cassell v. Carroll, 24 U.S. (11 Wheaton) 134, 148-49 (1826).
} 
Subsequent transfer of the 13,000 acre Carrollton Manor distinguished the son as Charles Carroll of Carrollton. ${ }^{62}$

By 1765 Charles Carroll of Carrollton had finished his studies in France and at the English Inns of Court and had returned to Maryland where he served as Charles Carroll of Annapolis's willing apprentice. By and large the son and father worked together agreeably. There were, however, several bones of contention. They agreed on the strategies for managing their 40,000 acres of land and their 285 slaves, but there was discord as to how to treat the portfolio of $£ 24,000$ sterling loans at interest. The old Annapolitan insisted on extracting compound interest that the young Carrolltonian thought to be usurious. ${ }^{63}$

There was also disagreement on the Carroll family's future in Maryland. Charles Carroll of Annapolis had long suffered the indignities of a Catholic in a Protestant state. During the French and Indian War, for example, he had been outraged by the double-tax levied against him and other Catholics. While the father actively considered moving the family and its fortune to Catholic Louisiana, the son argued that they should stay and fight their religious war in Maryland. ${ }^{64}$

The American Revolution created a deeper family rift. Notwithstanding the religious persecution and discrimination that the Carrolls had suffered, they retained immense wealth and privilege. Popular rebellion carried with it the prospect of property redistribution, and some threat of an insurrection by servants and slaves. Old Carroll of Annapolis thought it not worth the risk. ${ }^{65}$

\footnotetext{
${ }^{62}$ Ronald Hoffman, Princes of Ireland, Planters of Maryland: A Carroll Saga, 15001782, at 142 (2000); Sally Mason, Charles Carroll and his Family, 1688-1832, in BALTIMORE Museum of Art, ANYWhere So long AS THERE Be Freedom, Charles CARroll of CARrollton, His Family AND His Maryland 9, 19-24 (An Exhibition and Catalogue 1975).

${ }^{63}$ Edward C. Papenfuse, Charles Carroll of Carrollton: English Aristocrat in an American Setting, in Baltimore Museum of Art, Anywhere So long as there be Freedom, Charles Carroll of Carrollton, His Family and His Maryland 35, at 43-45 (An Exhibition and Catalogue 1975).

${ }^{64}$ Sally Mason, Charles Carroll and his Family, 1688-1832, in BALTIMORE MUSEUM OF ART, Anywhere So long as there Be Freedom, Charles Carroll of CARrollton, His Family AND His MARYLAND 9, 22 (An Exhibition and Catalogue 1975).

${ }^{65}$ Ronald Hoffman, Charles Carroll of Carrollton, Conservative Revolutionary, 1776-1781, in Baltimore Museum of Art, ANywhere So long as there Be Freedom, Charles Carroll of Carrollton, His Family and His Maryland 35, at 35-36 (An Exhibition and Catalogue 1975).
} 
Young Carroll of Carrollton got caught up in the drift towards rebellion. In 1773 at thirty-six years of age he joined with other young Maryland aristocrats in an opposition to Governor Robert Eden's increase in land office fees for the new proprietor, Henry Harford. And by 1776 he had been swept up in the revolutionary movement. He went with Benjamin Franklin on an unsuccessful mission to find support in Canada. Upon his return he went to Philadelphia where in July he signed the Declaration of Independence as Charles Carroll of Carrollton, and thereby signaled his own independence from his domineering father.

Soon thereafter Carroll of Carrollton had second thoughts. The first independent Maryland Assembly met in 1777 and passed two significant laws. The first, a new tax system, shifted from a head tax to a tax on land and slaves, the two primary sources of the Carroll wealth. The second, the Legal Tender Act, was even more disadvantageous to Carroll interests. It authorized the payment of pre-war debt, including sterling obligations, with paper money. The Carroll fortune would have been devalued by one-third. ${ }^{66}$

Circumstances soon improved, however. In 1780 the Maryland Assembly repealed the Tender Act, thereby permitting the Carrolls to once again require debt repayment in hard English sterling pounds. And next the Assembly enacted a statute confiscating Loyalist property. Charles Carroll of Carrollton's political wisdom was vindicated. But for his choice to be a Revolutionary rather than a Loyalist the family fortune would have been lost. ${ }^{67}$

Charles Carroll of Annapolis died in 1782. Charles Carroll of Carrollton, his son and heir, inherited 40,000 acres of land. ${ }^{68}$ At the rate of 4 shillings per hundred acres he would have owed the proprietor a tribute of $£ 320$ sterling per year, forever. Now Carroll owned the land outright, free and clear of any rent obligation owed to Calvert heirs. But did he?

\section{Henry Harford (1781-1783)}

\footnotetext{
${ }^{66}$ Ronald Hoffman, Charles Carroll of Carrollton, Conservative Revolutionary, 1776-1781, in Baltimore Museum of Art, ANywhere So long as there Be Freedom, Charles Carroll of Carrollton, His Family and His Maryland 35, at 38 (An Exhibition and Catalogue 1975).

${ }^{67}$ Robert J. Brugger, Maryland, A Middle Temperament, 1634-1980, at 318-333 (1988).

${ }^{68}$ Edward C. Papenfuse, Charles Carroll of Carrollton: English Aristocrat in an American Setting, in Baltimore Museum of Art, Anywhere So long as there be Freedom, Charles CARroll of CARrollton, His Family and His Maryland 35, at 49 (An Exhibition and Catalogue 1975).
} 
With the surrender of Lord Cornwallis in 1781 Henry Harford lost any prospect of being fully restored to the Maryland proprietorship. He also found himself at a disadvantage in his efforts to recover to recover either the quit-rents owed to him by Maryland landholders, or the manor lands that his Calvert forebears had reserved to themselves. In 1780 the Maryland General Assembly declared it "highly improper for, and derogatory to, the citizens of this sovereign and independent state, to pay quit rent ... to the subject of a foreign prince." The citizens of Maryland "from the declaration of independence, and forever thereafter ... [were] exonerated and discharged from the payment of the aforesaid quitrent." ${ }^{69}$ Likewise the reserved Baltimore manors were away; at the same legislative session, an act was passed to "seize, confiscate and appropriate" all property owned by British subjects within the state. ${ }^{70}$

But perhaps Henry Harford had not lost everything. The Pennsylvania legislature had agreed to compensate the heirs of Thomas Penn for his reserved private lands and for the arrearage in quit-rents payments. The Virginia legislature allowed the Fairfax heirs, the proprietors of the "Northern Neck," to keep their manor lands. Maybe in light of these generous precedents, the Maryland General Assembly would reconsider. Moreover the treaty of peace signed in 1783 "earnestly recommend[ed]" that American properties be restored to Englishmen and further provided that debts that had been contracted prior to the war were to be honored. With hope in his heart and hat in his hand Henry Harford came to Maryland seeking recompense. He was accompanied by his uncle Sir Robert Eden, the former proprietary governor of Maryland, with whom he had settled his differences over the rights to Frederick Calvert's estate in $1781 .^{71}$

In 1785 Henry Harford submitted a Memorial to the General Assembly of Maryland wherein he requested payment for delinquent pre-revolutionary quitrents, for the capitalized value of future quit-rents, and for confiscated manors and reserved lands, at a sum total of 3327,441 . The Maryland Senate rejected his request. On of the few dissenters was Charles Carroll of Carrollton who would

\footnotetext{
${ }^{69} 1780 \mathrm{Md}$. Laws ch. 18.

701780 Md. Laws ch. 45.

${ }^{71}$ Vera F. Rollo, Henry Harford: Last Proprietor of MAryland 69-90 (1976); Paris Peace Treaty, Sept. 3, 1783, U.S.-G.B., 12 Treaties \& Other International Agreements of the United States of America 1776-1949, at 8 (Bevans, ed. 1974).
} 
have honored Harford's request. Carroll, one of Maryland's largest landholders, seemed concerned by the precedent of expropriation on such a grand scale. ${ }^{72}$

Henry Harford had more success in the English Parliament which had in 1783 passed a Compensation Act for those British subjects "who ha[d] suffered in their ... properties ... in consequence of their loyalty to his majesty and attachment to the British government." ${ }^{, 73}$ Harford inflated his claim of losses in Maryland to $£ 447,000$ and received a total of $£ 90,000$ in recompense. He was given $£ 70,000$ for himself while payment of $£ 10,000$ to John Browning (on account of his wife Louisa) and $£ 10,000$ to Sir Robert Eden (on account of his wife Caroline) in satisfaction of Harford's outstanding obligations under the 1781 family property settlement. ${ }^{74}$

\section{THE OPINION OF THE U.S. SUPREME COURT}

Now forty years later Charles Browning had appeared, claiming to be the rightful Calvert heir and intent upon claiming a portion of the lost Calvert fortune.

At the time of the death of Frederick the $6^{\text {th }}$ Lord Baltimore in 1771 the sum total of all the annual quit-rents owed by all Maryland landholders was estimated to be $£ 8,518$ per year. Browning alleged that his mother, Louisa Calvert Browning, not Henry Harford was the rightful heir to the province of Maryland and that she had never received any payments. If he was correct he had a plausible claim to eight and a half years worth of unpaid rent or approximately $£ 72,403$. That amount was said to be equivalent to $\$ 317,125$ in 1823 dollars. That amount would have the same "purchasing power" as $\$ 5,538,714$ today. ${ }^{75}$

Cassell v. Carroll was the 1825 test case designed "to try the right of Lord Baltimore's Heir and Devisee to recover the quit Rents on the Province from the death of Frederick Lord Baltimore in 1771 to the date of the act of Assembly

\footnotetext{
72 Memorial of Henry Harford (1786) (Text of the Memorial and the Proceedings thereon, published by order of the House of Delegates, General Assembly of Maryland), reprinted in Vera F. Rollo, Henry HARFord: LASt PROPRIETOR OF MARYlANd 141, 145-46 (1976).

7323 Geo. 3, c. 80 (1783).

742 J. THOMAS SCHARF, History OF MARYLAND 392-397 (1967 photo. reprint) (1879).

${ }^{75}$ Appellate Record for the United States District Court for the District of Maryland at 4, Cassell v. Carroll (4th Cir. 1823) (found in the Appellate Case Files of the U.S. Supreme Court, 17921831. Microfilm M214, roll number 65, case file number 1263 housed at the National Archives). See John J. McCusker, Economic History Services, Comparing the Purchasing Power of Money in the United States (or Colonies) from 1665 to 2003 (2004), at http://www.eh.net/hmit/ppowerusd/.
} 
abolishing the quit Rents in 1780." "[F]or the purpose of trying that question the suit [was] brought for the Rent on Doughoreagan Manor only[, to avoid] the trouble and expense of including all ... Patents ...." If the matter in dispute exceeded the sum of $\$ 500$ the federal courts would have jurisdiction because a subject of Great Britain was making a claim against a citizen of Maryland. ${ }^{76}$ For the purpose of assuring the jurisdictional amount would be satisfied the lawyers in the case, Daniel Raymond for the plaintiff and Robert Goodloe Harper for the defendant, stipulated to the fiction that the rent reserved on Doughoreagan Manor was $£ 100$ sterling a year, when in reality the reserved rent was only $£ 20$ a year. ${ }^{77}$

At the trial in the United States Circuit Court for the District of Maryland the judges (Associate Supreme Court Justice Gabriel Duvall and Circuit Judge Theodorick Bland) gave judgment for Carroll. Now that decision was on appeal to the United States Supreme Court. Carroll's trial lawyer and son-in-law, Robert Goodloe Harper, had died unexpectedly and a new advocate was needed to challenge the validity of pre-revolutionary quit-rents.

Old Charles Carroll of Carrollton retained young Roger B. Taney to lead the defense. Taney was one of Maryland's up and coming barristers, and as some indication of the national interest in the case, William Wirt, both a Maryland landholder and the Attorney General of the United States, also joined in the defense. Maryland trial attorney Daniel Raymond, who had unsuccessfully represented Louisa Browning's estate at the trial, retained Daniel Webster to help him argue the appeal. When the Supreme Court was in session Webster maintained a Washington City office and offered his services to less experienced lawyers. In Cassell v. Carroll, Daniel Webster, the foremost Supreme Court advocate of the day was pitted against Roger Taney who was destined to replace John Marshall as Chief Justice of the United States. ${ }^{78}$

\section{The Issues}

Frederick the $6^{\text {th }}$ Lord Baltimore had died in 1771, naming Henry Harford the $7^{\text {th }}$ Lord Baltimore. Harford had been recognized by the provincial government

\footnotetext{
${ }^{76}$ U.S. CONST. art. III, $\S 2$; Judiciary Act of 1789, ch. 20, $§ 11,1$ Stat. 73, 78-79.

${ }^{77}$ Appellate Record for the United States District Court for the District of Maryland at 4, Cassell v. Carroll (4th Cir. 1823) (found in the Appellate Case Files of the U.S. Supreme Court, 17921831. Microfilm M214, roll number 65, case file number 1263 housed at the National Archives). ${ }^{78}$ WALKER LEWIS, WiTHOUT FEAR OR FAVOR 85-91 (1965). Just three days before the arguments in Cassell v. Carroll Taney had retained Webster to help him argue the appeal in Etting v. Bank of the United States, 24 U.S. 59 (1826).
} 
of Maryland and the English Crown as Maryland's lawful proprietor. Harford's land office had collected the quit-rents due the proprietor until the Declaration of Independence in 1776. In time of war Maryland landholders stopped paying quitrents, altogether.

In 1780 during the course of the war the Maryland Assembly had enacted a statute confiscating all the property belonging to British loyalists, "debts only excepted." Loyalist property, including the vast land holdings of the proprietor, was confiscated. ${ }^{79}$

These exogenous events bracketed Louisa Browning's claim to the unpaid quit-rents. Assuming that Browning rather than Harford was the true heir to the proprietorship, the rents Carroll had paid to Harford for the years from 1771 through 1776 were paid to the wrong party. The 1780 statute that confiscated property belonging to British subjects did not include pre-existing debt. The quitrents on Doughoregan Manor for the years 1771 through 1780 constituted a debt unpaid to Browning and were therefore collectable, or so the argument went. ${ }^{80}$

The dispute between Browning's estate and Carroll raised two essential issues - one of confiscation the other of heirship. The confiscation issue was that of lawfulness - had the citizens of Maryland legally divested the Calvert heir to her or his entitlements? The heirship issue was that of entitlement-who was the legitimate heir to the quit-rents of the Calvert dynasty-Henry Harford or Louisa Browning?

\section{Confiscation}

The customary law of nations provided principles as to the right of a state to confiscate property. It was understood to be a right of war that ceased in times of peace. Hence Maryland's right to confiscate enemy property began in 1776 with the Declaration of Independence and ended in 1783 when Congress ratified the peace treaty ending the War.

The 1780 Maryland confiscation statue read as follows: "That all property within this state, debts only excepted, belonging to British subjects, shall be seized,

\footnotetext{
79 JOHn E. HowARD \& JAMES CARroll, JR., TO THE LANDHOLDERS OF THE STATE OF MARYLAND 20 (1825).

${ }^{80}$ JOHN E. HOWARD \& JAMES CARROLl, JR., TO THE LANDHOLDERS OF THE STATE OF MARYLAND 3-5 (1825).
} 
and is hereby confiscated to the use of this state." ${ }^{81}$ With respect to its meaning and application, questions lingered. Were the proprietor's quit-rents "property" within the meaning of the statute? Had quit-rents, past due and unpaid, become a debt and therefore within the statutory exception and not confiscated after all?

The 1783 peace treaty compounded the conundrum. Its fifth article provided, "that all persons who have any interest in confiscated lands, . . . by debts, ... shall meet with no lawful impediment in the prosecution of their just rights," and the sixth article further provided "[t]hat there shall be no future confiscations made" after the peace treaty was signed. Was the 1780 Maryland law incompatible with these treaty provisions and therefore void ${ }^{82}$

\section{Heirship}

The 1632 Maryland Charter created a hereditary proprietorship in the Barons of Baltimore. Akin to the English Crown, it passed down from generation to generation, from eldest son to eldest son, and in the absence of son in any generation the proprietorship would pass to a daughter. The proprietorship includes both seigniory rights (sovereign rights of governance) and property rights (ownership of land). ${ }^{83}$

In 1750 Charles the $5^{\text {th }}$ Lord Baltimore had reinforced the entailment with his will that transferred the province of Maryland to Frederick the $6^{\text {th }}$ Lord Baltimore in fee tail. When Frederick died, the proprietorship and all the appurtenant rights and privileges were destined to pass "to the heirs of his body." Charles' will went on to provide that if Frederick was to die without lawfully begotten issue, then the proprietorship should pass to Frederick's sister Louisa.

In 1761 Lord Frederick had undertaken to break the entail by a fictitious transaction of "lease and release" that purported to vest him with title in fee simple absolute. When he died Frederick attempted by his will to transfer the province of Maryland to Henry Harford, his illegitimate son.

These events had left the heirship to the Maryland proprietorship (including the entitlement to quit-rents) open to questions. Had Louisa Browning, as the last

\footnotetext{
${ }^{81}$ Confiscation Act, 1780 Md. Laws ch. 45, $\$ 2$.

${ }^{82}$ Paris Peace Treaty, Sept. 3, 1783, U.S.-G.B., 12 Treaties \& Other International Agreements of the United States of America 1776-1949, at 8 (Bevans, ed. 1974); Smith v. Maryland, 10 U.S. (6 Cranch) 286 (1810).

${ }^{83}$ MD. CHARTER (1632).
} 
living Calvert descendant, succeeded to the proprietorship (including the quitrents) under the original Maryland Charter? Should the quit-rents be considered seigniory rights of the Lord Proprietor that were not transferable by either deed or will? Had Lord Frederick successfully barred the entailment to the proprietorship so as to hold it in fee simple and to be able to transfer the quit-rents by his will to Henry Harford? Did Lord Charles Calvert's will effectively create a remainder interest in the quit-rents in Louisa Browning? These questions were presented to English Court of Kings Bench in 1775 in the case of Harford v. Browning. Lord Mansfield, the presiding judge, considered the questions "new, and of great difficulty" and declined to answer them pending further arguments. ${ }^{84}$

\section{The Court's Opinion}

The U.S. Supreme Court was briefed on these "important and difficult points" with "great ability and care" but in the final analysis Justice Story decided not to attempt the "extensive researches" involved in reaching a mature judgment. He found a simpler solution. ${ }^{85}$

The 1780 agreement purported to settle the title to the province of Maryland. The parties in interest were Frederick's executors, Henry Harper, John Browning (Louisa's husband), Sir Robert Eden, Caroline his wife, (the said Louisa and Caroline being the heirs at law of Lord Frederick) and a committee (a guardian) representing the estate of the disabled Louisa Browning (she being a lunatic). The terms of the agreement ceded the Maryland proprietorship to Harford and his heirs in return for payment of $£ 10,000$ to John Browning and his wife Louisa, and $£ 10,000$ to Sir Robert Eden and his wife Caroline. The agreement was approved by the British Parliament and the Crown.

Since Louisa Browning was not herself a party, the question arose as to whether the agreement was binding on her estate after her death in 1821. The settlement had been directed by the Court of Chancery and approved by Parliament. It was a bona fide assignment for the valuable consideration of $£ 10,000$ that had been used for her benefit during the ensuing forty years. Under these circumstances Justice Story ruled that Louisa was bound by the agreement

\footnotetext{
${ }^{84}$ Harford v. Browning, 15 Geo. 3 B.R. June 27, 1775, reprinted in Cassell v. Carroll, 24 U.S. (11 Wheaton) 134, 170 (1826).

${ }^{85}$ Cassell v. Carroll, 24 U.S. (11 Wheaton) 134, 147 (1826).
} 
and that the case could be disposed of "without attempting to analyse the learning which is involved in other[ points] of more complexity."

\section{Historical Significance}

The result in Cassell v. Carroll comes as no surprise. "If the claim . . . set up be established, every tract of land patented before the revolutionary war [would] be liable to a repayment of quit rent[s] . .." ${ }^{87}$ Charles Carroll of Carrollton and other Maryland landholders would be forced to pay as much as ten percent of the fair market value of their land to Charles Browning.

Although the result was predictable, the opinion in Cassell v.Carroll comes as a disappointment; it raises a number of complex legal questions of great difficulty and then chooses not to answer them. But the record in Cassell v. Carroll provides a trove of history. It exemplifies the triumph of capitalism over feudalism. It reminds that money matters. And it reveals private property as the creation of "an act of naked judicial legislation" 88 while suggesting that the "rule of law" is sometimes premised upon "collusive legal fiction."

\section{A Triumph of Capitalism over Feudalism}

The lives and fortunes of the Calvert dynasty and the Carroll family intertwined for over a century. Charles Carroll the Settler had first arrived in Maryland in 1688 expecting to receive a ministerial post from his Catholic coreligionist Charles Calvert, the $3{ }^{\text {rd }}$ Lord Baltimore. He discovered on his arrival that the Protestant succession to the English Crown had reconstituted Maryland a royal colony. Devout Catholics were foreclosed from public office by the requirement of an oath of allegiance to the Anglican Church. Maryland's Lord Proprietor had been divested of his sovereignty and he had no governmental commission to offer the Settler.

In 1690 both Charles Calvert, the $3^{\text {rd }}$ Lord Baltimore, and Charles Carroll, the Settler, found themselves similarly situated. Both had come to Maryland to find tolerance for their Catholic faith and to seek their fortune. Both now found themselves subjected to religious discrimination and disqualification from public life. There was one immense difference, however. The $3^{\text {rd }}$ Lord Baltimore had been

\footnotetext{
${ }^{86}$ Cassell v. Carroll, 24 U.S. (11 Wheaton) 134, 147 (1826).

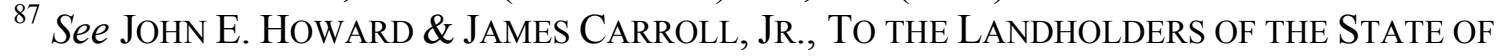
MARYLAND 3 (1825).

88 The quotation comes from: A.W.B. SiMPSON, A HiSTORY OF THE LAND LAW 34 (2d ed. 1986).
} 
permitted to keep the family's proprietary rights in the lands of Maryland. He was very wealthy. Charles Carroll the Settler on the other hand had no money and no job. He was penniless.

One hundred and thirty-five years later, in 1825, the situation had dramatically changed. The Calvert name had died out, but not before they had forsaken their faith, lost their fortune and fallen into dissipation, illegitimacy and dishonor. The Carrolls lived on as the leading Catholic family of Maryland. The scion, Charles Carroll of Carrollton, was an honored Founding Father of the Republic and one of the richest men in North America. How had this come to be?

Perhaps the Calverts were suffering the wages of apostasy and sin, but there seems to be a better explanation for their fall from grace. In today's parlance it might be said that the Calverts had a flawed "business plan." They undertook to emulate the medieval English Crown by creating and perpetuating a feudal fiefdom in the American wilderness. A stream of income from perpetual quit-rents would ensconce a Calvert dynasty in power and wealth. Entailment would keep the fiefdom in the family forever.

The Carrolls pursued a different strategy. They became capitalists. In three successive generations they maximized their profits. Charles Carroll the Settler accumulated capital the old-fashioned way. He married a wealthy widow. And when she died in childbirth he married the fifteen-year-old Mary Darnall. She was the daughter of Henry Darnall, Calvert's cousin and principal agent. The Settler went to work for his father-in-law in the Calvert's land office and through insider trading accumulated sixty thousand acres of land. After the Settler died his son and heir Charles Carroll of Annapolis took over management of the family's new wealth. He diversified the portfolio by becoming Maryland's largest lender and slaveholder and by establishing the Baltimore Iron Works. And his son Charles Carroll of Carrollton had the prescience to choose the winning side and to be a leader of the American Revolution. When the new Maryland Constitution confiscated loyalist landholdings the Calvert proprietorship came to an end. Abrogation of Calvert's quit-rents perfected the Carroll fortune.

Capitalism trumped feudalism!

\section{Money, Value and Exchange}

Money lies at the root of the controversy in Cassell v. Carroll. In 1707 the long forgotten English economist Alexander Justice made the following 
observation: "[m]oney in general is divided into two sorts, imaginary and real." Contemporary historian David Hackett Fischer explained the difference as follows:

Justice's "real money" is money of exchange. It is issued by virtually all sovereign states and consists of coins and paper that pass physically from hand to hand. Justice's "imaginary money" is called money of account. It exists only as an idea, and is used in bookkeeping and credit transactions. ${ }^{89}$

This dichotomy can be used to explain much of what happened in the saga of the Calverts and Carrolls.

The medieval feudal system functioned without the need for money in either sense. Land and labor served as the primary factors of production. Landlords compensated the mass of workers who were bound to soil with a share of their agricultural product. Underlords compensated overlords with military services. The overlords provided the Crown with a standing army. It was the rise of capitalism and the exchange of land, goods, and services in arms-length market transactions that made money essential.

During the time of Cassell v. Carroll England maintained a dual system. "Real money and imaginary money existed side by side." In England and Maryland, the pound sterling - worth twenty shillings or 240 pence - was the money of account. It was imaginary money. It did not exist in any tangible form as coins or paper currency. Two coins, the silver shilling and the gold guinea (worth 21 shillings), were the primary money of exchange. There were also other coins of smaller denominations. Gold and silver bullion were also valued by weight and used in sales transactions. ${ }^{90}$

Slowing the economic development in Maryland and other colonies was the chronic shortage of money of exchange. Due to the deficit in the balance of trade, money of exchange inevitably ended up back in England. Maryland created paper money but failed in its efforts to sustain its par value. Local money fluctuated in value but on average it was worth one-third less than its nominal pound sterling equivalence.

\footnotetext{
${ }^{89}$ David Hackett Fischer, The Great Wave: Price Revolutions AND the Rhythm of HISTORY 282 (1996).

90 David Hackett Fischer, The Great Wave: Price Revolutions AND the Rhythm of HISTORY 282-283 (1996).
} 
From the Calverts' point of view, one advantage of reserving quit-rents rather selling outright had been that it made their land more marketable. Buyers need not pay the full price with money of exchange. Quit-rents spread the payment of a portion of the purchase price over time, and since they were moderate in amount they could be readily "commodified" in tobacco or grain.

From the Carrolls' point of view, money posed the greatest risk of revolution. At the time of the Revolution the Carrolls were Maryland's largest lenders with a portfolio of bonds and mortgages valued at over $£ 80,000$ sterling. If a popularly elected assembly were to create new money of exchange, inflate its value relative to the benchmark pounds sterling, and ordain it to legal tender, the Carroll fortune would be measurably devalued. This is essentially what happened in 1778. But then in 1780 the Carrolls and other Maryland capitalists regrouped, and convinced the Assembly to change its mind. The Tender Act was repealed and the subsequent confiscation of the property of British subjects (including the Calverts' quit-rents) aggrandized the Carroll fortune.

Money matters!

\section{“An act of naked judicial legislation”}

In culture wars of today, social conservatives accuse "activist" judges of making decisions on an ad hoc basis and ignoring the "rule of law" with respect to private property. The critics support their position with a historical trope. Private property, they say, is the creation of a higher natural law. When during colonial times the English Crown usurped these rights, America's Founding Fathers declared their independence and established a new nation dedicated to the protection of "life, liberty, and property." Now an "imperial judiciary" is ignoring these "rules of law" and impinging on property rights by confiscating the real and personal private property of some people, and giving it to others. The critics call for judicial restraint and for the return of the law-making function to elected legislatures. $^{91}$

The case of Cassell v. Carroll reveals a very different history. During feudal times land was inseparably linked to family and social status. It lacked the most important characteristic of private property: it was not exchangeable. But as England moved towards a market economy there was a felt necessity to turn land

\footnotetext{
${ }^{91}$ Roger Pilon, Legislative Activism, Judicial Activism, and the Decline of Private Sovereignty, 4

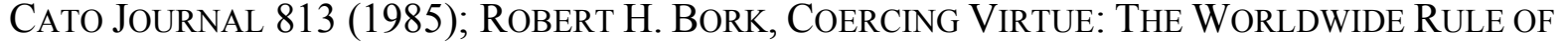
JUDGES (2003).
} 
into a commodity. In the late Middle Ages the English courts in an "act of naked judicial legislation inspired by strong views of public policy," made land transferable. Activist $15^{\text {th }}$ century judges unapologetically used the legal fiction of a collusive lawsuit to create private property. ${ }^{92}$

Charles Carroll of Carrollton and the other Founding Fathers came from America's wealthy elite. Carroll, for example, was heavily invested in slaves, land, and loans. From his perspective the replacement of the Crown with more representative form of government was a risky proposition. The popular will of freemen was untested - the assembly might redistribute land, abolish slavery, and devalue loans. But the potential gains were great. Territory won by "right of the sword" belonged to the conqueror. Under the rule of law, there was a right to confiscate the property of the enemy during the war. ${ }^{93}$

If a successful Revolution took place, the property of the Crown and the Calverts could lawfully be expropriated. "[T] he people of each state ... [would] themselves [become] sovereign ... and in that character hold the absolute right to . . . the soils under them ...."94 Carroll could be excused from the payment of quitrents and could take a share of the loyalist property.

Carroll joined the cause of independence, and benefited mightily. The populist tendencies of Maryland General Assembly were held in check: It reaffirmed the entitlement of Carroll and other Revolutionists to "all property derived to them" from the Calverts. ${ }^{95}$ And "to the victors went the spoils." The legislature expropriated "all property within this state . . . belonging to British subjects. ${ }^{" 96}$ Carroll stopped paying quit-rents to the Calverts and he seized the opportunity to take a share of some of the confiscated loyalist lands at a bargain price. $^{97}$

This story of Cassell $v$. Carroll turns the arguments of social conservatives upside down. It portrays the cherished right to freely market one's property for top dollar which today's property rights advocates fervently seek protect as nothing more than the creation of 15 th century judicial activism. And it depict the

\footnotetext{
92 A.W.B. Simpson, A History OF THE LAND LAw 129-137 (2d ed. 1986); Taltrum's Case, Y.B. 12 Edw. 4, 19 (1472).

${ }^{93}$ Smith v. Maryland, 10 U.S. (6 Cranch) 286 (1810).

${ }^{94}$ Martin v. Lessee of Waddell, 41 U.S. 367, 410 (1842) (Opinion by Chief Justice Taney).

${ }^{95}$ Md. CONST., DeClaration OF Rights. art. V.

${ }^{96}$ Confiscation Act, 1780 Md. Laws ch. $45, \S 2$.

${ }^{97}$ See, e.g. Smith v. Maryland, 10 U.S. (6 Cranch) 286 (1810).
} 
American Revolution as an assault on private property of the ruling elite with the "rule of law" serving as an excuse for the massive confiscation of the land from the rightful owners. 


\section{SOURCES}

\section{Cases}

Calvert's Lessee v. Eden, 2 H. \& McH. 279 (Md. 1789).

Cassell v. Carroll, 24 U.S. (11 Wheaton) 134 (1826).

Harford v. Browning, 15 Geo. 3 B.R., June 27, 1775, reprinted in Cassell v. Carroll, 24 U.S. (11 Wheaton) 134, 153-171 (1826).

Martin v. Lessee of Waddell, 41 U.S. 367 (1842).

Smith v. Maryland, 10 U.S. (6 Cranch) 286 (1810).

Taltrum's Case, Y.B. 12 Edw. 4, 19 (1472).

\section{Treaties, Statutes \& Constitutions}

Confiscation Act, 1780 Md. Laws ch. 45.

Legal Tender Act, 1778 Md. Laws ch. 9.

Maryland Constitution, Declaration of Rights, $\S 5$.

Paris Peace Treaty, Sept. 3, 1783, U.S.-G.B., 12 Treaties \& Other International Agreements of the United States of America 1776-1949, at 8 (Bevans, ed. 1974).

\section{Books}

Baltimore Museum of Art, ANywhere So long AS THERE Be FreedOM, Charles CARRoll of CARROLlTON, His FAMILY AND His MARYLAND (An Exhibition and Catalogue 1975).

Robert H. Bork, Coercing Virtue: The Worldwide Rule of Judges (2003).

GEORGE C. BRODRICK, ENGLISH LAND AND ENGLiSH LANDLORDS (FARNBOROUGH, ENGLAND, GREGG INT’L 1968) (1881).

Robert J. Brugger, Maryland, A Middle Temperament, 1634-1980 (1988).

David Hackett Fischer, The Great Wave: Price Revolutions and the RHYTHM OF HISTORY (1996). 
Clarence P. Gould, The LAND System In MARYland 1725-1765 (1913).

Ronald Hoffman, Princes of Ireland, Planters of Maryland: A Carroll SAGA, 1500-1782 (2000).

JoHn KILTy, The LANDHOLDER's Assistant, AND LAND-OfFICE GuIDE (Baltimore, G. Dobbin \& Murphy 1808).

Walker Lewis, Without Fear or Favor; A Biography of Chief Justice ROGER BROOKE TANEY (1965).

A.W.B. Simpson, A History OF THE LAND LAW (2d ed. 1986).

\section{Articles}

Beverly W. Bond, The Quit Rent in Maryland, 5 MARYLAND HISTORICAL MAGAZINE 350 (1910).

Sally Mason, Charles Carroll and his Family, 1688-1832, in Baltimore Museum of ART, ANYWHERE So long as THERE BE FreEdom, Charles CARroll of CARrollton, His FAmily and His Maryland 9-33 (An Exhibition and Catalogue 1975).

Ronald Hoffman, Charles Carroll of Carrollton, Conservative Revolutionary, 1776-1781, in BALTIMORE MuSEum OF ART, ANYWHERE So LONG AS THERE Be Freedom, Charles Carroll of Carrollton, His Family and His MARYLAND 35-41 (An Exhibition and Catalogue 1975).

Edward C. Papenfuse, Charles Carroll of Carrollton: English Aristocrat in an American Setting, in BALtimore Museum of Art, ANYwHere So LONG AS THERE BE FreEdom, CHARles CARRoll of CARROLlton, His FAMILY AND HIS MARYLAND 35-57 (An Exhibition and Catalogue 1975).

Roger Pilon, Legislative Activism, Judicial Activism and the Decline of Private Sovereignty, 4 CATO JOURNAL 813-833 (1985).

Garrett Power, Parceling Out Land in the Vicinity of Baltimore:1632-1796, Part I, 87 MARYLAND HISTORICAL MAGAZINE 453 (1992).

Tim Thornton, The Palatinate of Durham and the Maryland Charter, 45 AMERICAN JOURNAL OF LEGAL HISTORY 235 (2001). 


\section{Records and Documents}

MD. ChARTER (1632).

1711 Doughoregan Patent.

1730 Deed --Grantor Charles the $5^{\text {th }}$ Lord Baltimore entails province of Maryland.

1750 Will--Charles the $5^{\text {th }}$ Lord Baltimore devises had province of Maryland to Frederick the $6^{\text {th }}$ Lord Baltimore in fee tail, remainder to Charles' daughter Louisa.

Maryland Legal Tender Act 1778.

Maryland Confiscation Act 1780.

http://www.mdarchives.state.md.us/megafile/msa/speccol/sc2900/sc2908/00 0001/000203/html/am203--269.html

1780 Agreement between Henry Harford, John Browning, and Sir Robert Eden.

Pamphlet-- MARYLAND, TO THE LANDHOLDERS OF THE STATE OF MARYLAND (1825). 
Appendix 1. Cassell v.Carroll Chronology

\begin{tabular}{|c|c|c|}
\hline English Crown & Barons of Baltimore & Carroll Family \\
\hline $\begin{array}{l}1625 \text { Reign of Charles I } \\
1632 \text { Charles I grants Maryland Charter } \\
1649 \text { Charles I beheaded } \\
1649 \text { Commonwealth } \\
1653 \text { Protectorate } \\
1660 \text { Restoration of Charles II } \\
1685 \text { Reign of James II } \\
1689 \text { Glorious Revolution } \\
\text { Reign of William \& Mary }\end{array}$ & $\begin{array}{l}1632 \text { Cecil Calvert, 2d Lord Baltimore } \\
\text { Lord Proprietor of Maryland } \\
1675 \text { Charles Calvert, } 3^{\text {rd }} \text { Lord Baltimore } \\
\text { Lord Proprietor of Maryland } \\
1689 \text { Maryland a Royal Colony } \\
\text { Charles Calvert, } 3^{\text {rd }} \text { Lord Baltimore: } \\
\text {-divested of seignory (sovereignty) } \\
\text {-retains proprietary lands } \\
\text { - appoints Henry Darnall, land agent }\end{array}$ & $\begin{array}{l}1661 \text { Charles Carroll the Settler born in Ireland } \\
\text { (CCS) } \\
1685 \text { CCS studies law in England } \\
1688 \text { CCS immigrates to Maryland } \\
1689 \text { CCC marries Martha Ridgeley Underwood } \\
1690 \text { Martha Ridgeley Underwood dies } \\
1694 \text { CCS: } \\
\text {-marries Mary, daughter of Henry Darnall } \\
\text {-works in Henry Darnall's Land office } \\
1696 \text { CCS begins acquiring proprietary land on } \\
\text { large scale }\end{array}$ \\
\hline
\end{tabular}




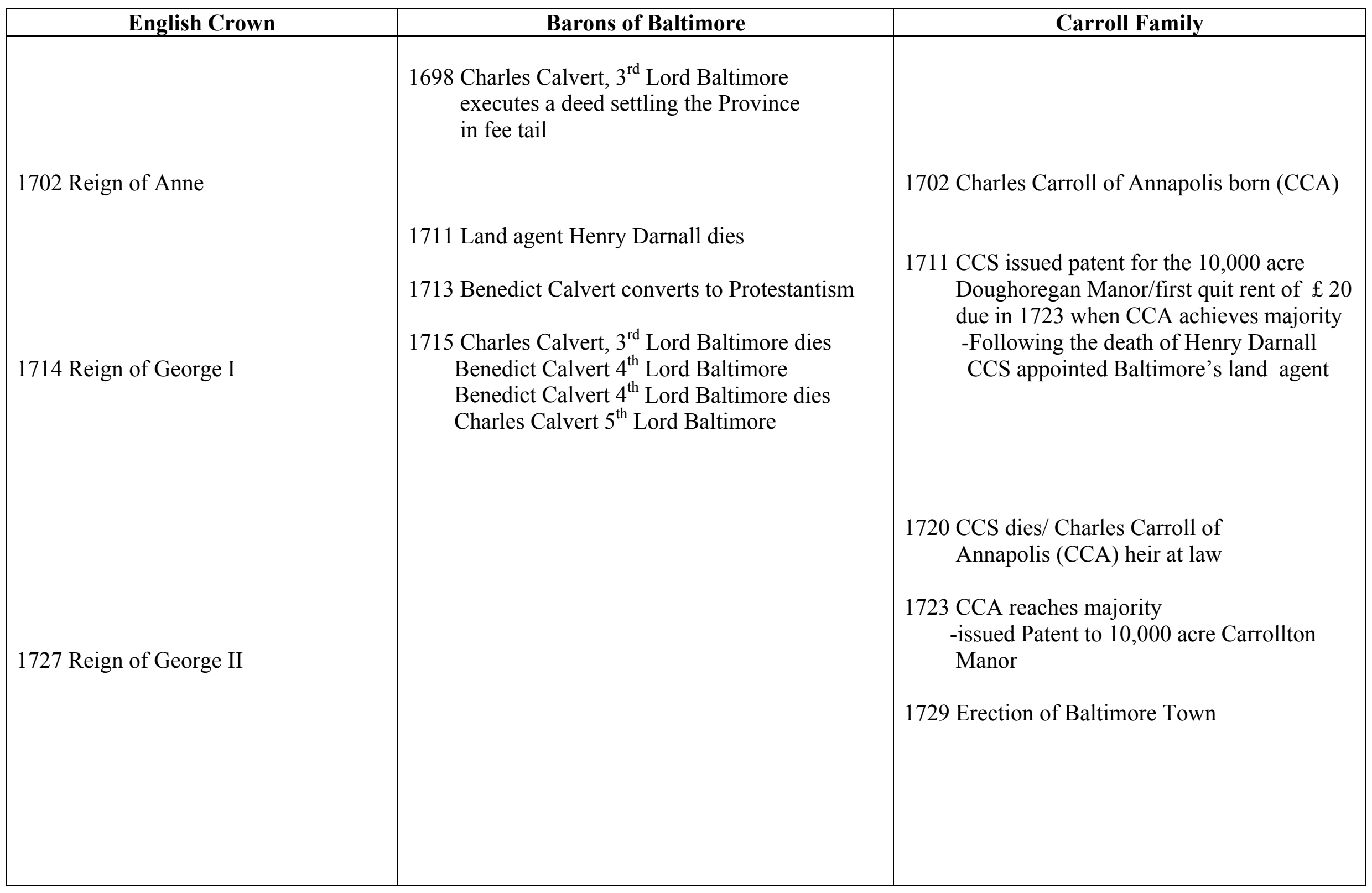




\begin{tabular}{|c|c|c|}
\hline 1760 Reign of George III & $\begin{array}{l}1730 \text { Charles Calvert } 5^{\text {th }} \text { Lord Baltimore executes } \\
\text { deed settling Province in fee tail male with a } \\
\text { remainder to himself in default of male issue } \\
1751 \text {-Charles Calvert } 5^{\text {th }} \text { Lord Baltimore dies } \\
\text { leaving a will transferring the Province to } \\
\text { his son Frederick in fee tail and in default of } \\
\text { issue remainder to Charles' daughter, Louisa } \\
\text {-Frederick } 6^{\text {th }} \text { Lord Baltimore } \\
\\
1761 \text { Frederick } 6^{\text {th }} \text { Lord Baltimore attempts to } \\
\text { dock the entail on the Province by deeds of } \\
\text { lease and release } \\
1762 \text { Louisa marries John Browning } \\
1771 \text { Frederick } 6^{\text {th }} \text { Lord Baltimore die leaving } \\
\text { a will transferring Province to his } \\
\text { illegitimate son Henry Harford } \\
1772 \text { Louisa Browning sues Harford challenging } \\
\text { his entitlement to Province; suit unresolved } \\
1772 \text { Henry Harford accepted as Maryland as } \\
\text { Lord Proprietor/ Harford county established }\end{array}$ & $\begin{array}{l}1737 \text { Charles Carroll of Carrollton (CCC) born } \\
\text { the illegitimates son of CCA and } \\
\text { Elizabeth Brooke } \\
1757 \text { CCA and Elizabeth Brooke marry } \\
1765 \text { CCA grants CCC Carrollton Manor } \\
1771 \text { CCA pays all quit rents due on his landed } \\
\text { estate to Harford }\end{array}$ \\
\hline
\end{tabular}




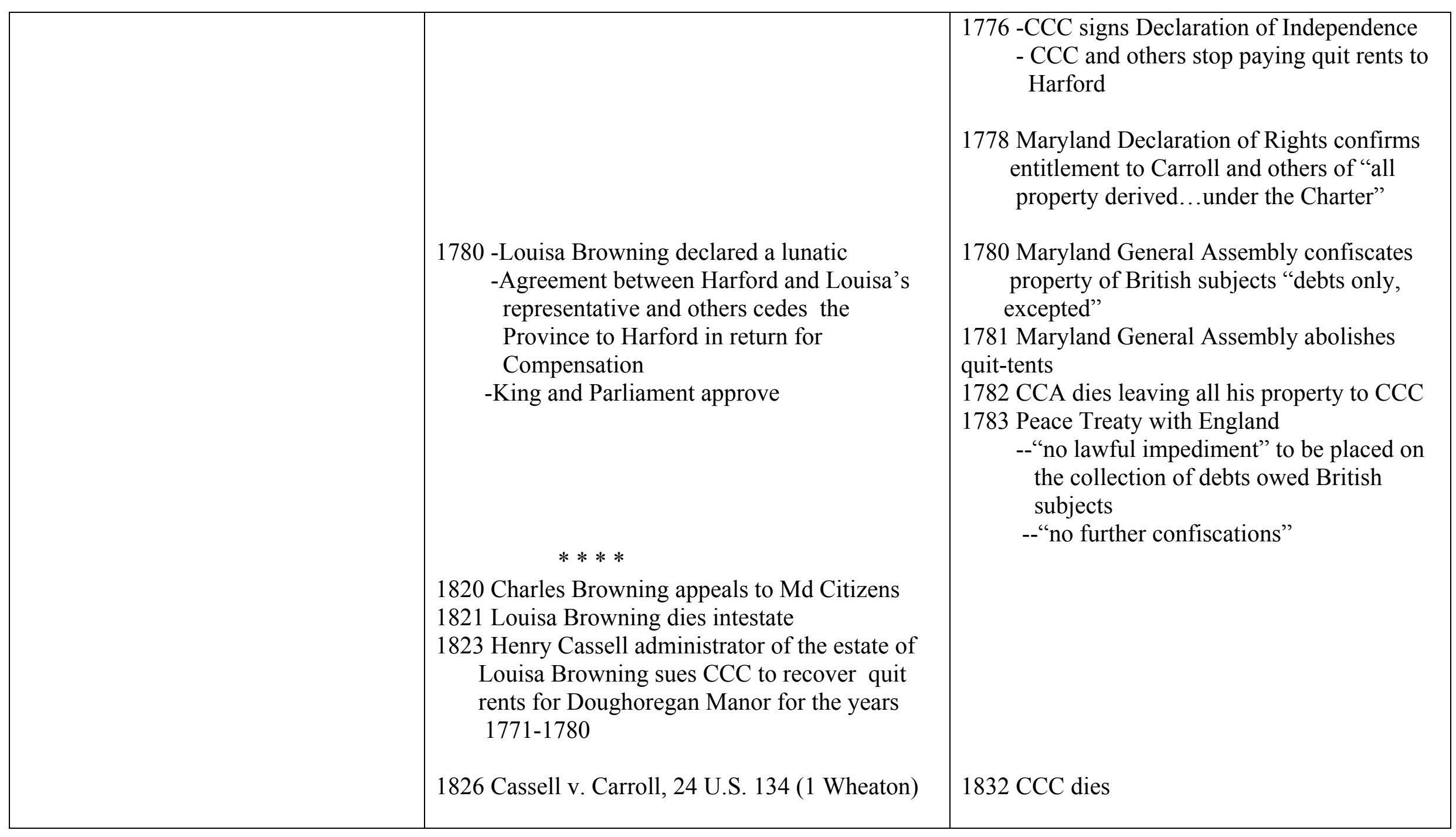

